Проф. др Валентина Питулић Универзитет у Приштини

са привременим седиштем

у Косовској Митровици

Филозофски факултет

valentina.pitulic@pr.ac.rs

\title{
ФОЛКЛОРНИ ПОДТЕКСТ У ПРИПОВЕДАЧКОЈ ПРОЗИ ПЕТРА КОЧИЋА
}

У раду ћемо се бавити фолклорним подтекстом у приповедачкој прози Петра Кочића како бисмо показали да је свој књижевни опус градио на фону народне традиције. У поступку Петра Кочића наћи ћемо готово све облике колективног памћења, како у облику обредно-обичајне праксе тако и у поступку транспоновања жанрова народне традиције у уметнички текст.

Из богатог опуса културе средине о којој је писао Кочић је у своје дело транспоновао оно што је видео у средини у којој је живео а то су: поштовање празника, славе, лирске и епске песме, као и обреда и прелаза (рођење, свадба и смрт). У раду ћемо показати која је функција елемената традиционалне културе и на који начин их писац транспонује у уметнички текст.

Кључне речи: традиција, празник, песма, јунак, жена, лепота, тужбалица, ропство.

Бавећи се традиционалном културом Срба Јовановић каже да традиционалним обрасцима културе у један народ „потврђује свој идентитет, односно оно што је у њему константно, непроменљиво и исто“ (Јовановић 2014: 38). Као носилац културног идентитета она није имагинација, већ 
представља „живу реалност“. За Марију Тодорову традиција представља избор онога што је вредно да се пренесе будућим генерацијама (Todorova 1999: 14-35).

У колективном памћењу Срба доминира култ предака, као својство свих патријархалних заједница (Чајкановић 1994: 123-132). У патријархалној култури породица је имала кључну улогу (Малиновски 1970: 15-25). Патријархални образац живота не само да је чувао обичаје који су имали улогу сабирања, већ је и преко неговања обредно-обичајне праксе одржавао контакт са оностраним, које је утицало на живот колектива и појединца. Живећи и стварајући у средини која је неговала патријархални образац живота Петар Кочић се у свом књижевном опусу бавио ликовима који су одраз онога што је та средина чувала, као образац свакодневног живота. Писац у своје стваралаштво уноси одређене облике традиционалне културе средине у којој је и сам поникао.

Традиција ${ }^{1}$ се у приповедачкој прози Петра Кочића огледа у неколико видова. Један од њих је фокусирање празника као важног маркера догађаја, који је уједно и искорак из свакодневног времена и улазак у сакрално време. Празник је, како наводи Бојан Јовановић, „укидао уобичајена правила световног живота“ (Јовановић 2000: 11) где се успостављају две реалности, световна и сакрална. Код Петра Кочића уочавамо сталну потребу да важне догађаје

„Назив традиција потиче од латинског глагола trado, tradere у значењу предати, дати, давати даље, предати у руке, односно његовог именског адеквата traditio који значи предање везано за усмену традицију приповедања, обичајну праксу, веровања и животне обрасце. Српски назив за тај шири аспект наслед-

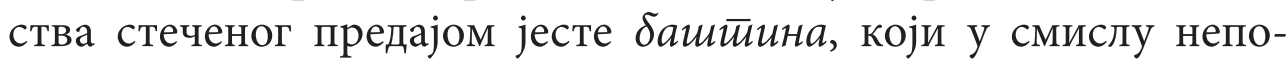
средног наследства значи очевину, родно место. У том смислу предање није само усмена духовна култура, већ и знање и вредности садржине у обрасцима мишљења и понашања који су изабрани из дотадашњег искуства да би се пренели наследницима“. Бојан Јовановић, у „Памћење и самозаборав“, Orpheus, Нови Сад, 2014, стр. 38. 
позиционира у односу на празник где ће сакрално, празнично време (Елијаде 2013: 110-126) бити у функцији одређивања времена дешавања радње. Тако ће приповетку из босанског сеоског живота Туба почети реченицом: „Освануо је лијепи, насмијани Ђурђев-данак. Све у радости и неописаном миљеу плива и топи се“ (Кочић 1972: 19). У приповеци Јаблан главна радња, борба бикова, догађа се на Преображење („Сјутра је Преображење, а уједно и царски дан. Сјутра ће се код кнежеве куће огледати Јаблан и Рудоња" (Кочић стр. 62). Празником Преображења писац је наговестио симболичну промену позиције српског народа у Аустроугарској. Победом Јаблана над Рудоњом писац је био на трагу успостављања односа хтонског и соларног, односно вечите опозиције светлост/тама.

Петар Кочић је у свом поступку користио успоравање радње да би се бавио декором празничне атмосфере. Код њега је празнични декор важан поступак преко којег своје ликове уводи у радњу. Он слика бујање вегетације где се у свим порама природе осећа „пробуђен живот“. На основу транспозиције готових облика обредно-обичајне праксе примећује се да је писац добро познавао још увек живу традицију свога краја, коју је укључивао у структуру уметничког текста.

Кочић је своје виђење традиције померио ка посебном позиционирању природе, која се углавном поклапа са осећањем ликова. Међутим, специфично је да Кочић не само да слику природе поистовећује са осећањима својих ликова; он то ради и са доживљајем празника. Ђурђевдан, „празник који је сачувао доста веровања и обичаја који магијским путем треба да осигурају напредак и плодност стоке и поља“ (Недељковић 1990: 72) на необичан начин доводи у везу са обредношћу коју не дефинише јасно. Када у центар стави човека и природу он их доводи у везу тако што се фокусира на осећања која су нејасна, где човек под утицајем природе „хоће да препукне од милине“, а та нејасноћа непознатог и јесте онај исконски, архетипски слој који се отима времену и 
историјском тренутку. Он доводи у везу не само човека са природом, већ и човеков однос према Богу који је радостан, са осећањем велике захвалности: „Хвала ти, боже, на твоме дару“ (Кочић 1972: 19).

Петар Кочић констатује да је ђурђевданско сунце чудновато и „старе подмлађује, а младима полет даје“ (Кочић 1972: 19). Када говори о природи он је на трагу исконске радости и у дослуху са њом. Писац се задржао на традиционалној култури Срба у свом крају, остављајући драгоцен податак о слављењу Ђурђевдана, када су се девојке љуљале 2 на љуљашкама певајући ђурђевданске песме.

Петар Кочић за недељу каже да је „света“, а у култу земље користи термин „црна и света земљица“. Он приступа земљи као Великој мајци (Нојман 1994: 52) из које се све рађа и у коју се све враћа. У српској традицији земља је представљена као женски принцип. Душан Бандић говори о томе да су „таква схватања била уобличена у представу о женском божанству познатом по називу земља или Велика мајка“ (Бандић 1991: 74). У приповеци Гроб слайке душе овај култ је посебно наглашен када стари Мијо, који је остао потпуно сам, брани своју земљу за коју је везан. Он је сигуран да ће на њега пасти проклетство ако угаси огњиште: „Пустите ме да се пошљедњи пут исплачем на својој земљи. Земљо моја, мајко моја“ (Кочић 1972: 68). Земља се овде појављује као архетипска представа Велике мајке, уз развијен култ огњишта које је било централно место у кућиз и око кога су

2 „Љуљање на љуљашкама и витлање на витловима је магијско. Обавља се у дане зимског периода, управо како где, од Божића до Ђурђевдана. Најраспрострањеније је у седмици Беле недеље пред ускршњи пост. У народу сеприређивало као катартично средство, да би се тело ослободило злих зимских духова, затим као лустративно, а сада служи за забаву омладини“. (Срйски митиолошки речник, Ш. Кулишић, П. Ж. Петровић, Нолит, Београд, 1970, стр. 197)

3 „Оно што је олтар у храму то је огњиште било у кући. Готово сви домаћи обреди обављали су се од рођења до смрти на огњишту. Код Црногораца је тешка заклетва огњиштем. Оно се није скрнавило било чим. Гравидне жене га нису брисале. Грешници 
се одвијале радње везане за обреде прелаза (рођење, свадба и смрт). У прози Петра Кочића, код последњег обреда прелаза, смрти, налазимо оплакивање мртвих, односно тужбалицу која представља „прастару обредну песму као саставни део мртвачког култа“ (Пешић, Милошевић-Ђорђевић 1996: 254) али се писац није бавио текстом ове индивидуалне обредне песме. Кочић ће у приповеци Туба само констатовати да су: „Јадне мајке почеле нарицати за својим синовима, као да су их покопале, па се с гробља кући враћају“ (Кочић 1972: 35). Писац тужбалицу, која се изговара у обредном контексту, тачно у одређено време, измешта ван обреда да би појачао значење и непристајање одласка српских младића у аустроугарску војску. Он не даје текст тужбалице већ само наглашава атмосферу у којој српске мајке жале за својим синовима који служе туђину.

У стваралаштву Петра Кочића присутни су готово сви облици традиционалне културе у којој се, између злих и добрих сила налази човек. Писац своје ликове смешта у простор деловања магијских радњи које утичу на судбину човека. Петар Кочић је добро познавао веровања у свом крају и његови ликови се налазе у простору деловања магијских радњи. Када Ђуро у приповеци Бурини зайиси говори о томе да не спава и да ће бити да је оболео каже: „Све ме нешто боде у очи... не могу спават. Чини ли су, набача ли је, уроци ли су?“ Када су у питању болести у народној традицији веровало се да демон болести улази у тело, а да је узрок туђа рука, односно како је народ веровао урокљиве очи, ${ }^{4}$ чини, односно магија. У овој приповеци Ђуро сумња на урокљиве очи удовице Ђурђије преко које су зле силе деловале на њега.

су се исповедали на огњишту. Стари људи умирали су на њему.“ (Срйски митиолошки речник, Нолит, Београд, 1970, стр. 220)

4 „Уричу углавном старије личности, које имају густе и састављене обрве и оне које имају продоран поглед својих црних, плавих и зелених очију, и вештице.“ (Срӣски митиолошки речник, стр. 291) 
Петар Кочић користи и народне формуле (Lord 1990: 68-91) како би најбоље приказао традиционалну културу Срба коју је вешто фокусирао и на посебан начин инкорпорирао у свој текст. Девојка која креће на рад облачи снежнобелу кошуљу и писац позајмљује формулу описа српске девојке из народне књижевности. Писац даје слику не само њеног лица, већ и хода, типично за усмено наслеђе, односно лирску песму. Писац ће девојку сликати поступком певача лирске народне песме: „Златна свиона коса окружава високо и ведро чело, под којим се необичним жаром свијетле грахорасте очи, осјенчене густим дугачким обрвама које једва да се не састају“ (Кочић 1972: 24). Поступком народног певача, Кочић прелази на сликање хода: „онај поносити, делијски ход, како лијепо доликује витком и правилно развијеном струку. А њедра, пуста њедра! Округла и једра, да пукну од једрине. Кад би стала, па наслонила пуне руке на накићену тканицу, па те погледа оним враголастим очима: на моју душу, да си Краљевић Марко морао би задрхтати.“ (Кочић 1972: 24). Из епске традиције Петар Кочић преузео је књиге староставне. ${ }^{5}$ Говорећи о Симеону Ђаку, на почетку приповедања даје објашњење: „Света је ово и мудра књига. У њој је исписана и запечаћена судбина свију земаља, свију народа, свију манастира, текија, цркава и други 'божји' богомоља. (Кочић 1972: 107). У епским народним песмама нема даљег објашњења о књигама староставним, док је Петар Кочић отишао корак даље. Он упућује на вредност староставних књига у коју се не сумња и преко које се спасава и поје-

5 „Епско-поетска реалија наших народних песама. По народном схватању, старе књиге које се обично у цркви, или на каквом двору налазе, из којих упућено лице (најчешће угледан и правичан свештеник, или ђаче самоуче) може да прорекне будућност. Исто књиіе иаросииавне, иаросииавник, вероватно асоцијација на старе рукописне црквене књиге“. (Радмила Пешић, Нада Милошевић-Ђорђевић, Требник, 1997, стр. 117) 
динац и колектив. Писац се обраћа читаоцу и упућује на њихов значај: „Земље и народи! Слушајте ријечи њезине и спасавајте се!“ (Кочић 1972: 109).

Кочић је посебно место у својој прози посветио обредима прелаза, где доминира слика свадбе. Он је ставља у миље раскошне јесени и обредни контекст. Писац у први план ставља невесту, која и јесте главни актер у овој иницијацији. Она, као носилац главних обредних радњи, кићењем скреће пажњу од утицаја злих сила (Карановић 2010: 108-140). Писац се придржава строгих правила обредности када у свој текст уноси свадбу. Он је транспонује у оном облику у којем је живела у његовом крају. У кићењу девојке, посебно место заузима босиљак, са својом апотропојанском моћи (Чајкановић 1994а: 36-43). Ни девојачка ни невестина лепота није статична, она се преноси на момке, и ту Кочић употребљава стих из усмене традиције: „Савила би по небу облаке, делај не би по земљи јунаке“ (Кочић 1972: 25).

Код Кочића су јасно позиционирана два слоја, соларни и хтонски. Писац је градио своје ликове на два плана, односно два амбијента. Један је пун светлости, готово пасторалан, а други хтонски, предео таме, са благим нагласком деловања злих сила. У оном делу приповедачке прозе која припада соларној категорији налазимо слике предела где све плива у радости. Ливаде су окупане сунцем, на њима пасу стада, да би се одједном фокусирао на предео хтонског, у зиму са великим снеговима. Код Кочића је препознатљив поступак фокусирања важних хришћанских празника, који су били маркери позиционирања догађаја важних за колектив. Муке чобана догодиће се о Часним веригама, један од јунака издахнуће на светог Николу. Место где долази до сусрета младих је сабор, место увођења девојке у коло, a Кочић сусрет обично веже за важан хришћански празник. У приповеци Ту $\delta$ то ће бити крај манастира, на Малу Госпојину, док мајка бунцање ћерке Тубе у сну покушава 
да спречи призивајући Светог Пантелију, њихову крсну славу. У приповеци Гроб слайке душе писац каже: „У зиме неђе, пред Часне вериге, врати се с дјететом у село“" (Кочић 1972: 72). Туба у приповеци Ту $\delta а$ Благоју, као у народној песми, баца јабуку, која је имала важну улогу „у односима између момка и девојке, при просидби и свадби“ (Чајкановић 1994а: 95), док ће њена мати предложити да јој лије страву како би је вратила из стања бледила. Кочић слика читав поступак народног исцељивања чији су чувари биле жене. Тубина мати узима пушчано зрно, олово, дели га на пола, један ставља у застук, а други на машице и ставља на ватру да се олово истопи, а онда: „Стара поврже машу, насу у једну здјелицу воде, прекрсти је и нешто прошапта, па онда сали с маше растопљено олово.“ (Кочић 1972: 27). Кочић транспонује у своје приповедање низ магијских радњи у којима се, како наводи Малиновски, заснива „на искуствима у којима се истина не открива разумом већ деловањем емоција на људски организам“ (Малиновски 1971: 15-35). Традиционална култура која је нашла место у стваралаштву Петра Кочића појављује се и у облику манифестације женског принципа као хтонског. У приповеци Бурини зайиси слика жене Ђурђе дата је као манифестација демонског: „Ђурђија јаше на вратилу, Ђурђија одузима марви млијеко, Ђурђија баца омразу између човјека и жене; у Ђурђије су 'ваке , у Ђурђије су 'наке очи... (Кочић, стр. 58). Она је добила све атрибуте вештице, ${ }^{6}$ онако како је представа о женским демонима живела у народу.

6 „Док вампири, по правилу, проводе време и делају засебно, сваки за свој рачун, вештице се, као и други женски демони, с времена на време удружују, у циљу договора и разоноде, а понекад заједно врше и нападе на људе. Пре него што ће поћи на састанак, намажу се оне неком нарочитом машћу, изговоре басму, и тако добију могућност летења, и евентуално постају невидљиве узјахавши потом на вратило“. (Веселин Чајкановић, Сйара срйска релиїија и мит̄олоїија, СКЗ, БИГЗ, Просвета, Партенон, М.А.М, Београд, 1994, стр. 218) 
Кочић посебну пажњу посвећује оном делу традиције где се преплићу паганска и хришћанска веровања. У покушају да врати кћер од љубавне ватре и ноћног бунцања она користи традицију предхришћанских времена, саливање олова, док у исто време користи и молитву која је директно упућена Богу и крсној слави, Светом Пантелији: „Боже милостиви, сачувај ме од сваке невоље и жалости, милости ти твоје! Свети Пантелија, крсно име, не дај нечастивом под наш кров“ (Кочић 1972: 21). Заправо, старица се обраћа Богу да их сачува од сваке невоље и жалости. Она, дакле, апстрахује појмове, невоље и жалост, каже како призива Светог Пантелију, крсну славу, да не дозволи нечастивом под кућни праг. Овде се најбоље види да је постојала, што би рекао Душан Бандић, „народна религија Срба“ (Бандић, 1991: 7-17) где постоји стална потреба за конкретизовањем апстрактних појмова. Бог је милостив, и она га призива да их заштити од општих појмова, сваког зла, док је конкретизовање дома као места обитавања породице директно у власти Светог Пантелије који брани дом од нечастивог. Кочић је у своје приповедање инкорпорирао и крсно име које његови јунаци користе и у свакодневном говору, у жанру говорних народних творевина, посебно заклињања, („тако ти крсног имена" (Кочић 1972: 31)). Појам Бога налазимо и у изрекама („Боже ме прости“ или „ако Бог да“). Честе су и изреке („Ђе си био - ниђе. Шта си радио - ништа“, „нити си ми род ни помози Бог“, „тешко оном кога други брани“). Код Кочића налазимо и благослов („Збогом пошо, Благи! Боже са срећом“) као и изреке попут „дрво на дрво чојек на чојека“. Свештеник се заклиње: „ванђеља ми и часне трпезе“, на слави се одговара на здравицу „Бог ти дао здравље“, али налазимо или клетву „не д’о ти Бог ни овог ни овог свијета“ или: „Еј, Ђурђија, да бог да, сестро, и данашња света неђеља-небеска царица, никад среће не имала. „Да Бог да, девет година иза прага сунца 
гледала, па нит' могла живити, ни умријети! Шта учини ово од мене“ (Кочић 1972: 57).

Петар Кочић користи и поступак транспоновања различитих жанрова народне књижевности где посебно место заузима лирска народна песма, за коју ће рећи да се пева „нако по старински“ (Кочић 1972: 82). Повремено ће се чути војничка песма коју певају младићи спремни за војску, али оне имају елегичан призвук због напуштања девојака и служења у туђој војсци:

„Мислио сам да ме жени бабо,

Али ме је оженио швабо,

Ој, девојко, драга душо моја,

Ој, девојко, драга Маро моја“

(Кочић 1972: 35)

Ово је песма коју певају младићи. Међутим, како би изразио тугу девојке којој драги полази на војску Кочић користи песму коју пева девојка:

„Ој, јабуко, моја зеленико,

Све те љето у њедрије носа;

Нит те једо, нит те коме дадо,

Већ сам те је драгом оставила

Јесен а мој драги оде.“

(Кочић 1972: 39)

$* * *$

„Јесен дође, а мој драги оде;

Ђе ли ћу ти презимити зиму“

(Кочић 1972: 161)

Да би приказао љубав између девојке и младића Кочић посеже за формулама традиционалне културе и то за оним које су доминантне у лирској народној песми. 
Девојка и младић изражавају љубав дарујући једно другом јабуку. У приповеци Кроз свјешилосии писац користи лирску народну песму да би показао појачану љубавну емоцију између двоје младих. Слично поступку Боре Станковића, кроз ноћ се разлеже љубавна притајена песма која у себи садржи фини ерос, који се код Кочића претвара у враголасти кикот девојака, на чијим грудима, као у лирској формули „на облим, дјевојачким њедрима пресијавају (се) дуги блистави гердани“ (Кочић, стр. 171). После овог описа разлеже се песма:

„Љуби, драги, колико ти драго; Само немој изгристи по лишцу...”

(Кочић 1972: 171)

Или:

„Дојке расту, јелеци пуцају, Срце иште, удати се хоће“

(Кочић 1972: 170)

Петар Кочић није користио само лирску песму да би насликао своје ликове. Он негује врло богату епску традицију која се огледа у начину епског приповедања, али и у призивању косовског завета и изгубљене царевине. У приповеци Kog Марканова йочка један одјунака приповеда шта смо некада имали. Призивање славне прошлости указује на опозицију некад/сад. У тој опозицији доминантно је некада: „Имали смо своје царство, своје цареве и јунаке, своју снагу и господство, па данас ништа“. (Кочић 1972: 76). Епска традиција је присутна не само у архетипском сећању на славну прошлост већ и у неговању гусала преко којих се преносило епско наслеђе: „О, кад мој отац загуди, па кликне из грла ону пјесну: Силан војска на Косово пала, силна војска српског цар-Лазара“. (Кочић 1972: 76) 
Кочић је посебно место посветио односу ми/они који је у традиционалној култури вековима постојао као релација овде/тамо, горе/доле, светло/тама; а „супротност светло-тама“ како наводи Ерих Нојман, „одређивала (је) и обликовала духовни свет свих народа“" (Нојман 1994: 92). Опозитан однос посебно је наглашен у односу према Аустро-Угарској. Она је, као у традиционалној култури, одраз хтонског док ће сакрални простор огњишта бити замењен повременим враћањем на архетипску представу рајског времена које је код Петра Кочића приказано кроз повремено призивање кнеза Лазара и косовских јунака. Транспоновање епске традиције у уметнички текст налазимо и у приповеци Исииинити зулум Симеона Бака где један од јунака, према Грмечу пева:

„Већ је крвца из земљице проврела, Земан дош'о, ваља војевати.“

(Кочић 1972: 87)

Код Петра Кочића налазимо сличан поступак као код Ива Андрића и Григорија Божовића, када се чује звук гусала. Традиционална култура не само да је присутна у повременој транспозицији епског наслеђа, већ је поступак сличан у одјеку који гуслар остварује у односу на околину. ${ }^{7}$ Код сва три писца гуслање буди архетип-

7 „И богами, свијет се лијепо и подобро прибра. Станко Ђаковић узе гусле, превуче два три пута гудалом, па кликну:

Свака стаза жали по јунака,

Равни Азић Заловару старог,

А трамошња Тому Ђаковића,

Гомјеница Парту игумана, И јунака Симеуна Ђака.

Вјешт Станкела, бог га не убиће, па превлачи ситно по струњи, а грло укоритио, па мисли чојек: не пјева, већ заједно са струњом плаче, јеца, цвили. Мене обузе некакав силан мерак, очи му успламћеше к’о двије живе жеравице, па подвисну' колико ме грло доноси: 
ске наслаге у свести појединца и колектива. Текст и звук гусала преносе се на слушаоца, уз катарзичан доживљај колективно-несвесног буђења архетипа јунака, а уједно и архетипа Спасиоца.

Код Петра Кочића присутан је косовски завет и стално враћање на јуначку прошлост и епску сакралност, на јуначке подвиге и погибије које су за Миодрага Павловића „свете службе, литургије, које се догађају једном заувек“ (Павловић 2000: 120). Посебно место у колективном памћењу етнопсихолошке заједнице о којој пише заузима архетип јунака јер „колективно памћење познаје само категорије и архетипове, а не само историјске догађаје и личности“ (Meletinski 1983: 75). Архетип јунака је изражен у сукобу са туђином, нарочито са Турцима. Чудесна је слика Срба у приповеци Мејgан Симеуна ђака у којој покушавају да одбране Манастир од Турака Крајишника. У тренутку напада Симеун ће призвати косовске јунаке: „За мном, браћо! За мном, ко се часним крстом крсти и чији су стари на Косову кости оставили за вјеру и отечество!“ (Кочић 1972: 101). Попут поступка народног певача који из колектива издваја јунака на исти начин и Петар Кочић из масе људи која крећу да брани манастир издваја Симеуна који неустрашиво позива наоружане Србе да крену за њим. Необична је слика свештеника који пред напад „очата војинствену молитву и освети барјак, па га с благословом предаде Станку Ђаковићу“ (Кочић 1972: 101). Овај поступак Петра Кочића под-

- Стој! Буди мене миран, Асан-беже Чеко, булешику ти твоју! Гинућемо, браћо, сви ћемо гинути за ову свету ћабу!

- Сви ћемо гинути! - оде одјек гором и планином из пет стотине грла.

- 'Вала народу, који ће нас тако спомињати кад вечерас погинемо, бранећи Христов олтар и свету ћабу од мрски' и нечастиви' Агарјана! - јекну покојни Партенија к’о убоден, а глас му жалобитно задркта и сузе га облише.“ (Кочић 1972: 99) 
сећа на епско причешћивање српске војске пред Косовски бој, само што је сведена на причешћивање једног јунака из колектива: „онда мене исповједи и причести, а осталу војску само благослови и пошкропи водицом“" (Кочић 1972: 101). Петар Кочић је у свом стваралаштву дао посебно место поетици жртве где уочавамо да се ослањао на традицију која је почивала на жртвеном обреду. Кочић је на трагу жртвеног обреда који се увек одвија, како би рекао Петар Џаџић, „на епски, витешки начин, а то је по правилу, начин који се плаћа животом“" (Џаџић 1995: 207).

Петар Кочић је добро познавао традиционално наслеђе свога краја. Био је укорењен у традицији и транспоновао је у своју приповедачку прозу не само оно што је као дете затекао у средини у којој је поникао већ је у своје ликове уткао и будио архетипске представе својих предака. Транспозицијом различитих жанрова усмене традиције у свој текст Петар Кочић је успео да својим ликовима да обележје традиционалног миљеа у којем су обитавали и тежили да очувају угрожени идентитет. Архетипско наслеђе предака им је помогло да издрже све изазове ропства, а писац је, инкорпорирајући у подтекст своје традиционално наслеђе свога краја, оставио богат књижевни опус као сведочанство живота у тешком периоду ропства. Традиционално наслеђе у подтексту књижевног дела важан је поступак где писац, транспонујући слојеве културе конкретне етнопсихолошке заједнице, улазећи у индивидуално и колективно-несвесно, оставља податке о богатом духовном наслеђу које је било и начин живота и начин опстанка.

Слојевито приповедање Петра Кочића отвара могућност за ново читање и ново тумачење како фолклорних жанрова тако и свих облика традиционалне 
културе. Нека ово тумачење буде прилог проучавању стваралаштва писца који је добро осећао све невоље свог народа, познавао све облике његове традиционалне културе и који је, у подтексту своје приповедачке прозе, сачувао сећање на онај део колективне свести који је истом том народу помогао да опстане у тешким годинама ропства.

\section{Извори и литература}

Бандић, Душан. Нароgна кюижевности Срба у 100 йојмова. Београд : Нолит, 1991

Елијаде, Мирча. Светио и иррофано. Нови Сад, Сремски Карловци: Издавачка књижарница Зорана Стојановића, 2003

Јовановић, Бојан. Памћене и самозаборав. Нови Сад: Orpheus, 2014

Јунг, Карл Густав. О йсихолоїији несвесної. Нови Сад: Матица српска, 2003

Карановић, Зоја. Неঠеска невестиа. Београд: Друштво за српски језик и књижевност Србије, 2010

Кочић, Петар. Прийовијейке. Сарајево: Издавачко предузеће Свјетлост, 1972

Кулишић, Ш, П. Ж. Петровић и Н. Пантелић. Срйски мийолошки речник. Београд : Нолит, 1970

Lord, Albert B. Pevač priča. Beograd: Idea, 1990

Малиновски, Бронислав. Маїја, наука и релиїија. Београд: Просвета, 1971

Meletinski, Eleazar Mijsejevič. Poetika mita. Beograd: Nolit, 1983

Недељковић, Миле. Гоgишњи обичаји у Срба, Београд: Вук Караџић, 1990

Нојман, Ерих. Ист̄оријско ӣорекло свестии, Београд: Просвета, 1994

Павловић, Миодраг. Оїлеgи о нароgној и стиарој срйској кюижевностии. Београд: Просвета, 2000 


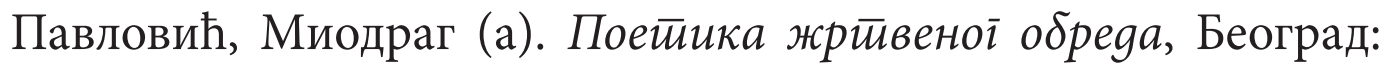
Просвета, 2000

Пешић, Радмила, и Нада Милошевић-Ђорђевић. Нароgна къижевности. Требник, Београд: Требник, 1997.

Todorova, Marija. Imaginarni balkan. Beograd: XX vek, 1999

Чајкановић, Веселин. О врховном бог̄y у сйарој срйској релиіији. Београд: СКЗ, БИГЗ, Партенон М.А.М, 1994.

Чајкановић, Веселин. Сӣара срӣска релиіија и митиолоїија. Београд : СКЗ, БИГЗ, Просвета, Партенон, М.А.М, 1994 Чајкановић, Веселин. Речник срйских народних вероваюа o биљкама. Београд: СКЗ, БИГЗ, Просвета, Партенон, M.A.M, 1994

Џаџић, Петар. Homo balcanicus, homo heroicus II. Београд: Завод за уџбенике и наставна средства, 1995

Valentina Pitulić

\section{FOLKLORE SUBTEXT IN NARRATIVE PROSE OF PETAR KOČIĆ}

\section{Summary}

In this paper we will show the process of transposition of folk motives in the poetics of Petar Kočić. Folklore subtext writer uses to show how faithfully the life of the collective and individual life in an environment that is threatening to destroy the identity of Serbian people under Austro-Hungarian rule.

In his storytelling prose writer used those symbols to show the most faithful patriarchal spirit of the Serbs who had just over preservation of ancient forms of culture managed to resist all temptations through which he passed. By positioning the light and dark layers below will show what is the relationship of tradition and new times, how the opposition up / down, there / here, we / they, and especially the relationship between tradition and the modern time. 
In this paper, we will monitor the function of certain symbols such as the fireplace, the mountains, the world of plants and animals, as well as occasionally invoking the ancestors, whose cult in the works of Petar Kočić highlighted.

Key words: tradition, holiday, song, hero, woman, beauty, dirge, slavery. 